\title{
关于更有效开展农村小学教育的方法探讨
}

\author{
崔致明 \\ 甘肃省临夏州永靖县青和学校 \\ DOI:10.32629/er.v2i5.1823
}

[摘 要] 在我国社会经济的发展过程中,教育是国家未来发展的动力,我国作为一个农业大国,农村人口占国家总人口的绝大 部分, 农村教育工作的实施效果对国家未来发展的影响较大。伴随教育体制改革的发展步伐, 农村小学教育工作逐渐暴露出一 些问题。本文通过分析目前农村小学教育工作的发展现状, 探讨了更有效开展农村小学教育工作的策略, 以期提高教学效果, 促进教育工作的进一步发展。

[关键词]农村小学; 教育方法; 有效性策略

教育在社会发展过程中发挥着重要的作用。而小学教育 又是整个教育工作的基础阶段, 在学生小学时期, 对其学习 习惯、行为等的引导, 对学生以后的学习与生活都有重要的 影响。所以应重视小学阶段的教育工作, 与我国城市地区相 比, 农村地区小学教育效果不理想, 具体原因包含许多因素, 为了促进教育工作的进一步发展, 应进一步探索提高农村小 学教育有效性的策略。

\section{1 农村小学教育现状}

1.1 师资力量薄弱

教师是教育工作的主要执行者, 教师的工作能力、工作 水平等对少年儿童身心发展、性格养成以及知识的获得等有 极大的影响。所以在教育工作中需要建立一支优秀的教师人 才队伍。这是确保教育工作取得理想效果的重要前提条件。 但是在实际的工作当中, 农村小学机构中存在教师数量不 足、素质偏低以及教育水平不高等问题。首先, 农村小学存 在教师数量严重不足的问题, 许多专科科目教师都是由其他 专业人才代替教学, 比如农村小学中的美术、体育等科目的 教学任务往往交给非专业教师来完成, 影响预期教学效果的 实现。其次, 由于农村地区的办学条件有限, 许多高水平人才 不愿意前往农村小学任教, 在新课程改革的过程中, 许多农 村小学教师在教学技能上都没有提升, 并且教学观念陈旧, 课堂上仅仅使用粉笔、黑板作为辅助教学设备, 长此以往, 农村小学教师无法实现教学方法和教学理念的创新, 教学水 平难以与城镇同期入职的教师保持在相同的水平线上。最后, 农村小学教师还朝着老龄化的方向发展, 经过调查与研究发 现, 农村小学任教的教师年龄在四十岁以上的占总体的百分 之七十, 老龄化问题使教师在教学过程中体力与精力不足, 教学积极性不高, 缺少工作热情与活力 ${ }^{[1]}$ 。

\section{2 教学设备落后}

与改革开放初期相比, 我国农村小学的教学环境和教学 设备已经有了很大的进步, 大多数小学已经由土房教学楼变 成了砖瓦校舍或多层楼房, 也从过去的单纯使用黑板、粉笔 的教学状态变为开始引进多媒体教学设备, 教学环境的改善 对于提高教学有效性来说有积极的作用。但是从目前的整体
情况来看, 农村小学的教学经费有限, 对各种先进教学设备 的引进力度不足, 很多学校缺乏足够的微机室、乐器以及体 育设施等, 在缺乏教学设备辅助作用的情况下, 农村小学教 育效果会受到相应的影响 ${ }^{[2]}$ 。

1.3 生源流失以及留守儿童问题

我国社会发展速度较快, 城市化建设工作持续进行, 越 来越多的农村青年人口倾向于前往城市寻求发展, 农村人口 流失严重, 作为小学生的家长, 更喜欢将孩子留在自己的身 边, 所以农村小学也存在严重的生源流失问题。一部分小学 生跟随父母前往城市学习和生活。还有一部分小学生家长前 往城市工作, 他们由祖辈或其他亲人代为抚养, 于是又出现 了留守儿童问题, 在留守儿童的成长过程中, 他们没有缺乏 监护者给予的行为与思想的正确引导, 这增加了教师的教学 难度。首先生源流失问题使得许多农村地区小学分布不均匀, 不同学校机构中学生数量差异较大, 在教师分配等方面缺乏 科学性, 影响教学有效性的提升。其次, 留守儿童问题使得教 师的课堂教学与管理难度提高, 加之教师的综合教学水平与 城镇小学教师相比有一定的差距, 所以经常出现教师管理, 学生不听的情况, 这对小学生的身心健康发展和农村教学水 平的提升来说都有重要的阻碍作用 ${ }^{[3]}$ 。

\section{2 原因分析}

结合农村小学教育现状中的几个主要问题, 分别分析其 对应的产生原因, 这样才能制定出解决对策, 提高课堂教学 效果。首先, 生源流失受我国社会发展与计划生育政策推行 的双重影响, 人们生活水平的提升使人们意识到教育对于未 来发展的重要作用, 所以对教育的重视越来越高, 父母更倾 向于将孩子送入教育水平较高的城市学校学习。其次, 社会 相关部门与机构对教育投资的不平衡, 是导致农村小学办学 条件有限的主要原因, 农村小学没有足够的办学经费, 无论 是在教育人才的培养、教学设备的引进还是在教学环境的建 设方面, 都存在许多缺陷, 影响教育工作的进一步发展。最后, 教师的教学水平不高, 经过分析发现, 农村小学教师与教学 课程的比例低于城市学校的平均标准, 也就是说, 农村小学 学生数量少, 但是对教师的需求比例下降不明显, 它们一样 
需要不同科目教师来任教, 而实际的教师数量无法满足对应 的需求, 就出现了一个教师任多职以及兼职教师等现象, 影 响教学效果的提升 ${ }^{[4]}$ 。

\section{3 关于提升农村小学教育有效性的策略研究}

3.1 完善教师队伍

提高教师的综合水平是提高教育有效性的重要方法, 作 为农村小学机构, 应积极寻求社会各界的支持, 比如在政府 的支持下吸引和鼓励优秀的示范专业毕业生投入到教育工 作中, 或者聘请优秀的语文、英语、数学等学科教师来我校 进行宣讲, 向本校教育人员传授先进的教学理念和高效的课 堂教育方法, 有助于促进农村小学中教师的整体进步。除此 之外, 农村小学管理者应重视出语文、数学、英语以外的学 科教学, 设置专业的学科教育人才进行教育工作, 这样才能 促进小学生各个学科知识的均衡发展, 促进农村小学教育水 平的提高 ${ }^{[5]}$ 。

3.2 增加农村小学的教育经费投入

教育经费不足是导致教学设备短缺、教学环境质量不高 的主要原因, 为了提高农村小学教育教学效果, 学校管理者 应积极吸引社会各界的资金鼓励和支持。同时人们也应提高 对农村小学教育的重视, 确保政府财政部门向学校拨发充足 的教育经费, 并确保这些经费的落实到位。同时学校也可以 发挥自身特色, 吸引社会人士的关注和支持, 借此来获得更 多的教育资金, 促进农村小学教育工作的整体发展 ${ }^{[6]}$ 。

3.3 重点关注对学生的身心教育

近年来我国农村地区留守儿童数量呈不断上升的发展 趋势, 农村小学教育中的留守儿童问题也越来越严重, 较多 的留守儿童给教师的教育工作带来较高的难度。留守儿童在 成长中缺少抚养者给予的足够的行为与心理引导, 导致他们 有许多不良的学习和行为习惯, 对此, 教师应增加对留守儿 童的身心健康指导, 在日常教学工作中提高对留守儿童的关 注, 用委婉的方法帮助留守儿童纠正错误的行为习惯, 用更 多的爱鼓励学生, 帮助他们建立自信心, 这样才能降低课堂 教学和管理难度, 综合提高农村小学的整体教学效果, 促进 留守儿童身心健康发展。

3.4 创新教学观念, 增加课堂教学方法
课堂教学效果直接影响农村小学的教育教学有效性, 所 以创新课堂教学方法对于促进农村小学教育工作发展来说 至关重要, 首先教师应更新自身的教育理念, 明确小学生在 课堂中的主体地位。然后结合小学生的兴趣爱好、学习习惯 等实际情况制定相应的课堂教学策略, 以调动小学生的学习 积极性, 提高课堂教学效果。综合来看, 新时期有效的课堂教 学方法有多媒体教学、游戏教学、情境教学等。比如数学教 师带领学生解决数学应用题时, 可以利用多媒体设备创设一 个与应用题中描述相同的生活场景, 赋予学生一个场景中的 角色, 加深学生的体验和理解, 这样有助于小学生寻找解题 思路, 提高解题效率。

\section{4 结束语}

综上所述, 与城市中小学的教育情况相比, 农村小学存 在教育资金有限、教师专业水平不高、教学设备不足以及学 生的教育和管理难度较大等问题, 针对这些问题的产生原因, 提出了提高教师综合水平、积极寻求更多的资金支持、重视 学生的身心健康发展以及创新课堂教学方法等。教师不仅要 关注小学生的学习情况, 更要注重小学生身体素质和心理素 质的发展, 在课堂中以学生为主体, 用小学生喜欢的方式开 展教学活动, 这样能够提高小学生的学习积极性, 营造良好 的教育氛围, 提升课堂教学效果, 促进农村小学生身体与心 理的健康发展, 有助于农村小学教育水平的整体提升。

\section{[参考文献]}

[1]陈斌.关于更有效开展农村小学教育的方法探索与 研究[J].读与写,2017,14(20):20-22.

[2]李兆平.新时代小学农村教育的发展思路[J]. 科教导 刊,2019,(3):143-144.

[3]魏文光. 农村小学教育现状及思考[ J]. 青春岁 月,2019,(5):251.

[4]郁家宝.提升农村小学教育质量的管理方法探究 [J]. 考试周刊,2018,(75):46.

[5]李宗政.农村小学语文课堂教学方式转变[J]. 考试周 刊,2019,(13):52.

[6]曹春花.优化农村小学英语学困生学习方法的探索 [J]. 读与写,2018,15(33):80. 